\title{
Reseptiivinen monikielisyys: miten suomenkielinen oppija ymmärtää viroa äidinkielensä pohjalta?
}

\author{
ANNEKATRIN KAIVAPALU \\ Tallinnan yliopisto \\ PIRKKO MUIKKU-WERNER \\ Itä-Suomen yliopisto
}

Tiivistelmä. Kun Euroopan neuvoston kieliohjelma edellyttää vähintään kahden vieraan kielen hallintaa, joudutaan pohtimaan tarvittavan kielitaidon tasoa. Riittäisikö se, että vierasta kieltä lähinnä vain ymmärrettäisiin? Kielitaidon yksi mahdollinen taso onkin reseptiivinen monikielisyys: vuorovaikutuksessa kukin keskusteluun osallistuja käyttäisi omaa äidinkieltään, jota toinen ymmärtäisi.

Reseptiivinen monikielisyys vaatii toteutakseen sukukielen ymmärtämistä, mutta miten hyvin suomalaiset todellisuudessa ymmärtävät viroa pelkästään äidinkielensä pohjalta? Asian testaamiseksi järjestettiin koe, jossa viroa lainkaan taitamattomille suomen opiskelijoille annettiin luettavaksi vironkielinen teksti, jonka sisältöä heitä pyydettiin kuvaamaan. Myös kääntämiseen kannustettiin. Lisäksi opiskelijoiden toivottiin reflektoivan kokemustaan: mikä on helppoa, mikä vaikeaa, ja millaisia keinoja merkityksiä rakennettaessa hyödynnettiin. Tulokset osoittavat odotuksenmukaisesti, että varsinkin yhteinen sanasto helpottaa ymmärtämistä. Toisaalta opiskelijat ovat tietoisia petollisista ystävistä, joten samanmerkityksisyyteen ei luoteta kritiikittömästi. Myös muu 
samanlaisuus - taivutusmuotojen, johtamisen, yhdistämisen ja lauserakenteiden samankaltaisuus - auttavat tekstin sisällön selvittämisessä. Vastauksista on myös pääteltävissä, että strateginen kompetenssi ja metalingvistinen tietoisuus edistävät ymmärtämistä.

Avainsanat: sukukielten omaksuminen; reseptiivinen monikielisyys; tekstinymmärtäminen; kieltenvälinen vaikutus; oppijan strategiat; viro; suomi

\section{Reseptiivinen monikielisyys}

\subsection{Määrittelyä ja historiaa}

Reseptiivisellä monikielisyydellä (receptive multilingualism), josta käytämme tästä lähtien myös lyhennettä RM, tarkoitamme artikkelissamme erityistä monikielisen kommunikaation tapaa: vuorovaikutuksessa kukin osallistuja käyttää toiselle puhuessaan omaa äidinkieltään ja ymmärtää toisen kieltä. (Ks. myös Zeevaert \& ten Thije 2007: 1.) RM siis vaatii tietoa toisesta, useimmiten sukukielestä. Lisäksi molemminpuolisen ymmärtämisen takaamiseksi voidaan äidinkieltä hiukan mukauttaa. Tavallisesti kyse on kuitenkin kuuntelijan käyttämistä monenlaisista kielenkäyttöstrategioista (Hufeisen \& Marx 2007: 308). Kuulija selvittää kielten samankaltaisuuden perusteella esimerkiksi sellaisen sanan merkityksen, joka on ollut hänelle aiemmin tuntematon (Ribbert \& ten Thije 2007: 75).

Ilmiönä RM ei ole uusi. Braunmüller on luonnehtinut myöhäiskeskiajan ja uuden ajan alun reseptiivisen monikielisyyden piirteitä. Monikielisyys on ollut tuolloin tavallisinta epämuodollisessa kasvokkaisessa kommunikaatiossa, varsinkin kaupankäyntitilanteissa ja muissa liikeelämän kontakteissa. Viestintä on ollut hyvin tarkoitushakuista, konteksti- ja vastaanottajariippuvaista. Kontaktin luominen on ollut erittäin tärkeää, ja kieltä on mukautettu ad hoc -periaatteella. Painopiste on ollut viestin välittymisessä ja interaktion tehokkuudessa. Tavoitteena ei ole ollut kohdekielen (produktiivinen) omaksuminen. Toista kieltä on 
"opittu" informaalisesti mutta mielekkään kielenkäytön kontrolloimana sekä kuuntelemalla että puhumalla: viestien tilanteittainen sopivuus on ollut määräävässä asemassa. (Braunmüller 2007: 30.)

Reseptiivinen monikielisyys on kiinnittänyt tutkijoiden huomiota jo vuosikymmenten ajan. Käytetyt termit ovat tosin vaihdelleet, ja on puhuttu muun muassa semikommunikaatiosta. Tätä Haugenin (1966: 153) ensimmäisenä käyttämää nimitystä on kritisoitu, koska se tuntuu viittaavan vain puolittaiseen ymmärtämiseen (ks. tarkemmin Zeevaert 2007: 105-107). Amerikan intiaanikielten puhujien kykyä viestiä monikielisesti tutkittiin 1950-luvulla. Skandinavian RM-kommunikaatio on edelleen ajankohtainen aihe mutta kiinnosti jo 1960- ja 1970-luvuilla. Yhtäältä espanjan ja portugalin, toisaalta slovakin ja tšekin suhde askarrutti tutkijoita 1980-luvulla. Viime vuosituhannen lopulta on tutkittu myös sitä, miten hyvin hollannin puhujat ymmärtävät friisiä ja afrikaansia. (Tutkimuksen historiasta ks. tarkemmin van Beezooijen \& Gooskens 2007: 250 lähteineen.) Uusimpien tutkimusten keskiössä on Hampurin yliopiston tutkimuskeskus (Research Center on Multilingualism), joka on perustettu vuonna 1999 ja jonka julkaisusarjassa Hamburg Studies on Multilingualism (HSM) on julkaistu muun muassa tässä artikkelissa laajasti hyödynnetty ten Thijen ja Zeevaertin toimittama teos Receptive Multilingualism (2007). Suomen ja viron tutkimus RM-näkökulmasta on ollut melko vähäistä, vaikka virolaisten ja suomalaisten keskenäinen kommunikaatio toimii usein reseptiivisen monikielisyyden pohjalta. Samantyyppisiä kysymyksiä on kuitenkin sivuttu muissa viitekehyksissä (esim. Laanekask 2003, Kaivapalu 2007, 2009).

\subsection{Monikielisen viestinnän vaihtoehto}

Mikäli mahdollisuuksia monikielisyyteen on, ei vuorovaikutus ole välttämättä yksikielistä. Kiel(t)en valinta on tärkeää, koska sen avulla osallistujat muun muassa määrittelevät tilanteen yhteisiin tavoitteisiin sopivimmaksi tai vaikkapa sen muodollisuusasteen (epä)formaaliseksi (Lüdi 2006: 15-16). Voisiko viron ja suomen yhteisiä ominaisuuksia 
hyödyntää entistä tehokkaammin yhtäl̈ltä vuorovaikutuksen edellytysten luojana, toisaalta viestintaitojen kertymisen vähittäisena edistäjänä? Olisiko tavoitteeksi asetettavissa toimiva RM-viestintä, ja mitä etua siitä olisi?

Monikielisessä vuorovaikutuksessa on paljon hyviä puolia, ja se tukee hyvin nykykäsityksiä kielitaidon vaihtelevista vaatimuksista. Euroopan neuvoston kieliohjelman mukaanhan päämääränä on, että jokainen eurooppalainen hallitsee kahta vierasta kieltä. Syntyperäisen kielitaidon tasolle pääsemisen tavoite on kuitenkin kyseenalaistettu ja tuomittu vanhakantaiseksi monessa yhteydessä (Lüdi 2006: 33-34), mikä näkyy esimerkiksi eurooppalaisen viitekehyksen tavoitetasoista (A2-C1).

Kun siis jostain kielestä riittää vähäisempi taito, olisi hyvä miettiä, miten alennettaisiin toisen kielen ymmärtämiskynnystä. Ymmärtäminenhän ei edellytä (lähes) syntyperäisen puhujan kielellistä kompetenssia (ten Thije \& Zeevaert 2007: 2). Usein arjen monikielisissä kohtaamistilanteissa riittää likimääräinen ymmärtäminen, jolloin joidenkin usein esiintyvien sanoen tunnistaminen ja tietäminen on tärkeää (Braunmüller 2007: 26). Mikäli ongelmia ilmaantuu, ne pyritään ratkaisemaan yhdessä. Neuvottelemisen merkitys korostuu, koska monikielisissä keskusteluissa kommunikaation ehdot ja strategiat eivät ole vakiintuneet sosiokulttuurisesti (Zeevaert \& ten Thije 2007: 4). Kyse ei ole pelkästään lingvistisestä tiedosta vaan monikielisistä kommunikaatiostrategioista. (Braunmüller 2007: 40.) Niistä voidaan neuvotella molemminpuolisen ymmärryksen takaamiseksi keskustelun aikana, tai niistä voidaan sopia ennakkoon.

Englanti lingua francana ei siis ole ainoa keino ratkaista Euroopan kieltenvälisen kommunikaation pulmia (ten Thije \& Zeevaert 2007: 2). Reseptiivistä monikielisyyttä voidaan pitää tasa-arvoisena viestimisen tapana. Siinä toteutuu demokratia, koska englanti ei ole kaikille yhtä helppoa. Lisäksi kyselyjen perusteella oman äidinkielen käytöllä on etuja. Oma identiteetti vahvistuu, kun se voidaan merkitä monikielisessä ympäristössä. Yksityiskohtien esittäminen on helppoa ja tarkkaa, ja jopa leikinlasku mahdollistuu. Valitettavasti skandinaavisen yhteistyön reseptiivinen monikielisyys on jäämässä globalisaation jalkoihin, 
ja usein kokouksissa käytetään englantia. Tämäkin ratkaisu on perusteltavissa demokratiaan vedoten: osallistujien katsotaan olevan yhdenvertaisia, kun kukaan ei puhu äidinkieltään. (Braunmüller 2007: 29; Nikko 2009:3.) Toisaalta nykyisin on jo kokemusta hollannin- ja saksanpuhujien RM-kommunikaatiosta (tutkimuksesta ks. Ribbert \& ten Thije 2007).

Edellä on mainittu useita monikielisen viestinnän ansioita. Lisäksi RM voi olla avuksi epämuodollisessa L2-oppimisessa (Braunmüller 2007: 40). Siksi tämänkin artikkelin tavoitteena on miettiä niitä reseptiivisen monikielisyyden hyötyjä ja mahdollisuuksia, joita suomen ja viron läheinen sukulaisuus tarjoaa.

\section{Suomi ja viro: avainkäsitteitä läheisen sukukielen omaksumisen näkökulmasta}

Reseptiivinen monikielisyys pohjautuu kielten samankaltaisuuteen. Viro ja suomi ovat tunnetusti läheiset sukukielet, jotka muistuttavat paljon toisiaan rakenteellisesti, leksikaalisesti ja funktionaalisesti. Kieltenvälinen vaikutus ${ }^{1}$ on siis suomenkielisten viron- ja vironkielisten suomenoppimisprosessissa huomattavasti enemmän mukana kuin etäisempien kielten opiskelussa. Kielten geneettinen ja typologinen tausta luo odotuksia, joihin liittyvät oppijan käsitykset ja kokemukset samanlaisuudesta ja erilaisuudesta. Läheisissä sukukielissä, kuten viro ja suomi, on asioita, jotka oppijat tavallaan jo valmiiksi osaavat lähdekielensä perusteella ja joita hyödynnetään erityisesti kielen vastaanottamisessa ja ymmärtämisessä. Oppijan on etukäteen kuitenkin vaikea tietää, mikä kielille todellakin on yhteistä, mikä vain tuntuu sellaiselta.

Lähde- ja kohdekielen järjestelmien läheisyys saattaa aiheuttaa sekä positiivista että negatiivista lähdekielen vaikutusta sen mukaan, diver-

Tässä tutkimuksessa tarkoitetaan termillä siirtovaikutus kielen rakenteellisten elementtien siirtämistä kielestä toiseen, kun taas termeillä kieltenvälinen vaikutus ja lähdekielen vaikutus korostetaan, että kieltenväliset vaikutusyhteydet nähdään laajempina ja kompleksisempina, myös kognitiivisessa, psykolingvistisessä ja sosiokulttuurisessa kontekstissa. 
goivatko vai konvergoivatko lähde- ja kohdekielen ilmiöt keskenään (esim. Ringbom 1987, 2007; Dechert ja Raupach 1989; Odlin 1989; Jarvis 2000). On huomattava, ettei lähdekielen vaikutus sinänsä ole kielteistä eikä myönteistä, vaan ainoastaan sen lopputulosta voidaan pitää kohdekielen kannalta myönteisenä tai kielteisenä (Sajavaara 2006: 11). Lähdekielen negatiivinen vaikutus on läpinäkyvä ja siihen on kohdistettu paljon tutkimusta. Se on kuitenkin sekundaarista verrattuna lähdekielen positiiviseen vaikutukseen (Ringbom 2007: 5). Opetellessaan uutta kieltä ihminen joko tietoisesti tai tiedostamattaan hyödyntää sitä tietoa ja taitoa, mikä hänellä on äidinkielestään ja/tai muista jo tuntemistaan kielistä. Kieltä opetteleva soveltaa uuteen kieleen niitä rakenteita ja ilmaisustrategioita, jotka hän ennestään hallitsee. Kielten samankaltaisuus helpottaa oppimista, ja onkin tunnettua, että suomenkielinen oppii ainakin jonkintasoista viroa ja vironkielinen suomea nopeammin ja pienemmällä vaivalla kuin ne oppijat, joiden äidinkieli eroaa huomattavasti suomesta tai virosta niin rakenteellisesti kuin leksikaalisesti. Kielisukulaisuuden tuottamasta hyödystä on näyttöä aikaisemmissa suomen- ja vironkielisten oppijoiden oppimiskäsityksiä ja -kokemuksia käsittelevissa tutkimuksissa (ks. tarkemmin Kaivapalu 2007; 2009).

Tämänsuuntaisista kokemuksista kertovat vironkieliset suomenoppijat esimerkeissä (1) ja (2). Esimerkissä (3) on puolestaan kuvattu suomenkielisen vironoppijan kokemuksia läheisen sukukielen omaksumisesta $^{2}$. Lähdekielen positiivinen vaikutus ilmenee näkyvimmin ymmärtämisessä kuin tuottamisessa (Ringbom 2007: 21-24), ja sen hyödyntäminen on strategiana käytössä varsinkin oppimisen alkuvaiheessa (Kaivapalu 2009):

(1) Minäkin katsoin aikoinaan suomen kanavia televisiosta ja sitä kautta se kielen "opiskelu" alkoi. Vähitellen aloin ymmärtää jotain, koska jotkut sanoista olivat tuttuja ja kontekstin avulla tuli asian perusidea selväksi. Sehän on auttanut lähinnä ymmärtämiseen, jolloin konteksti on ympärillä ---

2 Oppijoiden pohdintojen alkuperäistä suomenkielistä muotoa ei ole muokattu, mutta lihavoinnit on lisätty. 
(2) Opin suomen kielen aika nopeasti. En tarkalleen muista, miten omaksuin uudet sanat ja miten pärjäsin ensimmäiset viikot koulussa, mutta luulen, että alussa olin vain kuuntelijan roolissa ja seurasin muita. Jos joku kysyi jotakin, vastasin varmaan viroksi. Ainakin alussa se oli niin.

(3) En ollut ennen vaihtoon lähtöä opiskellut sanaakaan viroa, joten opiskelin vaihto-oppilasryhmässä, jossa kansallisuuksien kirjo oli varsin laaja. Siinä, missä intialainen poika yritti epätoivoisesti oppia erottamaan sanat $u k s$ ja $y k s$, pystyin minä melko vähällä vaivalla opettelemaan käyttökelpoisia fraaseja ja kielen rakenteita. Nominien taivutuksessa suomen kielen hyöty lienee merkittävin. Tietysti myös suuri osa sanastosta on yhteistä.

Kahden kielen järjestelmien kontrastiivisuus siis "ei ole kielen struktuureissa sinänsä, vaan siinä, miten kukin kielenkäyttäjä 'kokee’ kyseiset struktuurit”. Kielten samanlaisuus ja erilaisuus eivät toteudu kielen rakenteissa vaan kielenoppijan kognitiivisessa järjestelmässä oppijan tietona, kokemuksena, tulkintana, ennusteena tulevasta. (Sajavaara 1999: 123; 2006.) Kahden kielijärjestelmän rinnastaminen pelkästään struktuurien tasolla ei riitä kielen oppimisen tutkimuksessakaan, sillä kielten kuvailtavissa oleva typologinen etäisyys ei ole sama asia kuin kielenoppijan käsitys tai havainto niiden välisestä etäisyydestä (Sajavaara 1994: 22). Sen takia lähdekielen vaikutuksen tarkastelussa on ensisijaisen tärkeää vetää selvä raja todellisen, havaitun ja oletetun samanlaisuuden ja erilaisuuden välillä (Ringbom 2007: 7, 24).

Lähde- ja kohdekielen välinen todellinen samanlaisuus (actual) objective similarity) on kielitieteen aluetta, ja se on ainakin teoreettisesti kielijärjestelmien vertailun pohjalta selvästi määriteltävissä (ks. esim. Hannu Remeksen (2009) viron ja suomen taivutusjärjestelmien vertailu). Havaittu (perceived similarity) ja oletettu (assumed similarity) samanlaisuus heijastavat oppimisprosessia. Havaittu samanlaisuus on todellista samanlaisuutta huomattavasti laajempi ja enemmän variaatiota sisältävä psykolingvistinen käsite. Sen takia on havaitusta samanlaisuudesta käytetty myös termejä psykotypologia (psychotypology) (Eckman 2004: 517) 
ja samanlaisuuden psykolingvistinen todellisuus (Kaivapalu 2004: 65-70; 2006; Sajavaara 2006: 14). Havaittu samanlaisuus on vaikeammin määriteltävissä kuin todellinen samanlaisuus, sillä se riippuu paljolti oppijoiden henkilökohtaisista ominaisuuksista, kuten tarkkavaisuus, analyysikyky jne., ja myös kielenoppimiskokemuksista, ja sillä on erityisen iso rooli läheisten sukukielten ymmärtämisessä. Samanlaisuuden havaitseminen on yleensä potentiaalisesti tietoinen prosessi: useimmiten oppijat pystyvät verbaalisesti kuvaamaan havaitsemisprosessiaan vaikka eivät aina kieliopillista käsitteistöä käyttäen. Kohdekielen tuottamisprosessissa on olennaisinta oletettu samanlaisuus, joka kuten havaittu samanlaisuuskin on psykolingvistinen käsite. Oletettu samanlaisuus pohjautuu usein, joskaan ei välttämättä, havaittuun samanlaisuuteen. Jos oppija ei tiedosta lähde- ja kohdekielen välistä kontrastiivisuutta, hän olettaa, että kohdekieli toimii suunnilleen samalla tavalla kuin lähdekieli.

Kielen oppimisessa ja oppimisen tutkimisessa on tärkeää tehdä ero kielen ymmärtämisen ja tuottamisen välillä. Yhtä olennaista on nähdä ero myös kielellisten elementtien oppimisen (item learning) ja kielen järjestelmän oppimisen (system learning) välillä. Samoin kuin ymmärtämistaito kulkee tuottamistaidon edellä, kielellisten elementtien oppiminen edeltää kielen järjestelmän oppimista. Kielen oppimisessa voidaan nähda neljä eri vaihetta:

1) kielellisten elementtien oppiminen ymmärtämisessä (item learning for comprehension);

2) kielellisten elementtien oppiminen tuottamisessa (item learning for production);

3) kielen järjestelmän oppiminen ymmärtämisessä (system learning for comprehension);

4) kielen järjestelmän oppiminen tuottamisessa (system learning for production).

Kielen omaksuminen alkaa kielellisten elementtien omaksumisesta oppimisessa. Kaksi seuraavaa vaihetta, kielellisten elementtien oppiminen tuottamisessa ja kielen järjestelmän oppiminen ymmärtämisessä, 
kehittyvät tavallisesti rinnakkain. Kieltenvälinen samanlaisuus on relevantti ominaisuus kaikissa vaiheissa, vaikka vaikuttaa eri vaiheissa hieman eri tavalla. (Ringbom 2007: 98-100.)

Sekä suomenkielisten oppijoiden viron- että vironkielisten oppijoiden suomenopetuksen yhteydessä pohditaan usein, missä, missä määrin ja miten hyödynnetään lähde- ja kohdekielen lähisukulaisuudesta johtuvaa rakenteellista, leksikaalista ja funktionaalista samankaltaisuutta. On luonnollista, että suomenkieliset vironoppijat ja vironkieliset suomenoppijat tukeutuvat omaan äidinkieliinsä, jotka varsinkin kieliopillisilta rakenteiltaan ovat päällisin puolin melkein identtisiä. Tässä artikkelissa pohditaan, miten läheisen sukukielen vaikutus, oppijoiden metalingvistinen tietoisuus ja strateginen kompetenssi lisäävät edellytyksiä ymmärtää lähisukukieltä. Tutkimuksen tavoitteena on selvittää myös ymmärtämisen oppimisen vaiheiden järjestys. Täsmälliset tutkimuskysymykset esitetään seuraavassa luvussa.

\section{Tutkimuksen toteuttaminen ja tutkimuskysymykset}

Tutkimuksen tarkoituksena on selvittää, mitä suomenkielinen oppija ymmärtää vironkielisestä kirjallisesta tekstista äidinkielensä pohjalta ilman eksplisiittistä opetusta ja ilman aikaisempaa kokemusta viron kielestä. Tutkimuskysymykset ovat seuraavat:

1) mitä suomenkielinen oppija ymmärtää viron kielestä ja miten;

2) millainen on sanaston ja kieliopillisten rakenteiden osuus ymmärtämisessä;

3) miten kielijärjestelmän eri osa-alueet (fonetiikka, morfologia, syntaksi jne.) vaikuttavat ymmärtämiseen;

4) missä järjestyksessä lähisukukielen ymmärtämisprosessissa opitaan kielelliset elementit ja kielen järjestelmä.

Tavoitteena on keskittyä todellisen, mutta varsinkin havaitun samanlaisuuden rooliin. Aineisto on rajattu reseptiiviseen taitoon varsinkin sen takia, että kielen omaksuminen alkaa lukemisesta ja kuuntelemisesta: 
ennen kuin oppija pystyy tuottamaan opittavaa kieltä, on siitä edes jotain ymmärrettävä. Ymmärtäminen toimii pohjana tuottamiselle, ja sen tutkimisen avulla voi siis selvittää kohdekielen oppimisen edellytyksiä. Syynä nimenomaan kirjallisen tekstin valintaan opiskelijoiden tutkailtavaksi on se, että kirjoitettu teksti on useimmiten rakenteellisesti selvää ja kohesiivista, mikä oli testitilanteen rajallisen keston vuoksi hyvin tärkeää. Oppijoille jäi paremmin aikaa tekstin ymmärtämisen pohdintaan. Tavoitteena oli myös saada pohjatietoa tulevaa aineistonkeruuta varten, eli kyseessä on pilottitutkimus. Myöhemmin on tarkoitus testata myös puhutun kielen ymmärtämistä.

Käsiteltävänä oli teksti Mati Hintin oppikirjasta "Eesti keele õpik IX klassile" (1983) (ks. liite 1). Teksti on melko vaativa; se on alun perin tarkoitettu silloisen lukion ensimmäisen vuoden oppilaille johdannoksi viron kielen järjestelmän systemaattiseen opiskeluun yleiskielitieteellisellä taustalla.

Tutkimukseen osallistui 14 Jyväskylän yliopiston suomen kielen pääaineopiskelijaa, joilla ei ollut aikaisempaa tietoa eikä kokemusta virosta. Heillä kuitenkin on lingvisteinä hyvät edellytykset havaita rakenteellisia yhtäläisyyksiä ja eroavuuksia, mikä on otettava huomioon tuloksia arvioitaessa. Opiskelijoita pyydettiin viron kielen alkeiskurssin ensimmäisen tapaamisen aikana lukemaan teksti ja kirjoittamaan vapaamuotoisesti, mistä teksti yleisesti kertoo, mitä yksityiskohtia siitä ymmärretään ja miksi, sekä heitä kehotettiin kääntämään tekstiä sen verran kuin he pystyvät. Seuraavassa luvussa tarkastelemme ymmärtämistestin tuloksia ja oppijoiden havaintoja ymmärtämisprosessista. Esimerkkiaineistossa oppijoiden alkuperäiset tekstit on säilytetty muokkaamattomina. 


\section{Vironkielisen tekstin ymmärtäminen: havaintoja ja tuloksia}

\subsection{Mitä ja miksi ymmärretään: havaittu samanlaisuus}

Ymmärtämistestiin osallistujien joukossa ei ole yhtään oppijaa, joka ei olisi oivaltanut tekstin perusideaa. Kaikki testiin osallistujat ymmärtävät, että tekstissä puhutaan äidinkielestä, sen asemasta, sen merkityksestä ihmiselle, äidinkielen oppimisesta sekä siitä, mikä auttaa kielen oppimisessa (esimerkit 4-7):

(4) Tekstissä puhutaan äidinkielen opiskelusta, että äidinkieli on ihmisen side maailmaan ja yhteiskuntaan.

(5) Tekstissä kerrotaan siitä, miten äidinkieli vaikuttaa kielenoppimiseen ja -ymmärtämiseen. On tutkittu, että siitä on enemmän hyötyä kuin ihmiset yleensä uskovat.

(6) Luulen tekstin kertovan äidinkielestä, kielestä, joka on meille lähin: puhumme ja kirjoitamme sitä luontevasti. Omaa äidinkieltä ei kuitenkaan voi korvata, vaikka oppisi vierasta kieltä kuinka paljon.

(7) Äidinkielestä puhutaan ja kuinka tärkeä se ihmiselle on.

(8) Tekstistä ymmärsin, että aihe on äidinkieli, emakeel. Sen lisäksi ymmärsin vain irrallisia sanoja ja pätkiä.

Tekstin ymmärtämisen perustana on kolmentyyppistä tietoa: 1) lingvistinen ja kommunikatiivinen syötös, 2) lingvistinen ja maailmantieto sekä 3) konteksti (Ringbom 2007: 15). Tämänkin tutkimuksen tekstin sisällön ymmärtämisessä ovat todennäköisesti mukana muun muassa oppijoiden maailmantieto ja asenteet: oppijoiden kirjoitelmissa heijastuvat heidän käsityksensä äidinkielestä ja myös suhtautuminen siihen. Oppijat ovat tietoisia äidinkielen roolista ja tärkeydestä jokaiselle ihmiselle ja tälle kokemukselle saadaan tukea myös käsiteltävästä tekstistä. Kohdekielen ymmärtämisessä, johon riittää rajallinen rakenteen tuntemus ja joka ei vaadi niin paljon tarkkuutta kuin kohdekielen tuottaminen, havaitulla kieltenvälisellä samanlaisuudella on huomattavan 
tärkeä rooli (Ringbom 2007: 24-26). Suomenkielisten vironoppijoiden ymmärtämisprosessi perustuukin ensisijaisesti suomen ja viron kielen järjestelmien havaittuun yhdenkaltaisuuteen. Toisaalta on kyse yksittäisten kielellisten elementtien, sanaston ja rakenteiden, toisaalta kielten järjestelmien toimimisen samanlaisuuden havaitsemisesta (esimerkit 9-12):

(9) Ymmärsin tekstistä joitain yksittäisiä sanoja (emakeel=äidinkieli), verbejä (arvata, kirjutame), konjunktioita (ja, kui).

(10) Muutamat verbit tuntuivat tutuilta, pronominit (me, mida, seda) olivat ymmärrettävissä osittain suomen kautta, lauserakenne ymmärrettävissä.

(11) Ymmärtää muutamia sanoja, kuten óppimine, emakeel, on, tundub, koska ne muistuttavat suomen kielen sanoja. Sanajärjestys vaikuttaa suomen kielen sanajärjestyksen kaltaiselta.

(12) Ymmärrän tekstistä joitakin sanoja, jotka muistuttavat suomen kielen sanoja. Monista sanoista ymmärtää päätteet ja tunnukset, useista sanoista erottaa, mikä lauseenjäsen se on. Eräät verbimuodot ovat suomesta tuttuja.

Oppijoiden on helppo ymmärtää myös sanat tõesti, parandada, vähendada, kohendada, aitavad, maailma, jotka ovat sekä fonologiselta ulkoasultaan että merkitykseltään molemmissa kielissä samanlaisia. Ymmärtämisprosessissa korostuukin erityisesti verbien keskeinen asema lauseessa: samanlaisuuksien listaaminen aloitettiin useimmiten verbeistä.

Suomen ja viron taivutusmorfologian ja johto-opin rakenteellinen ja funktionaalinen samanlaisuus näyttääkin olevan sanaston samanlaisuuden ohella ymmärtämisprosessin avain. Oppijat yhtäältä tunnistavat helposti sanaluokat (konjunktiot, pronominit), päätteet ja tunnukset sekä taivutusmuodot, toisaalta hahmottavat yhdyssanat ja sanojen yhdistämisprosessin (esimerkit 13-14):

(13) Tekstistä ymmärsin sanojen taivutusmuotoja kuten keel: keele/s 
(14) Joissakin yhdyssanoissa yhdyssanojen osat voivat olla erilaisia, mutta merkityksen silti ymmärtää.

Syntaksin osalta ymmärtämistä auttavat samankaltainen sanajärjestys ja lauserakenne, mutta myös havaittu samanlainen konjunktioiden käyttö (esimerkit 15-16):

(15) Useista sanoista erottaa mikä lauseenjäsen se on.

(16) Sanajärjestys vaikuttaa suomen kielen sanajärjestyksen kaltaiselta; konjunktiot kuten et ja kui vaikuttavat tutuilta, vaikuttaa siltä, että niitä käytetään samalla tavoin kuin suomen kielessä

Suomenkielisten oppijoiden vironkielisen tekstin ymmärtämisen osatekijöitä voi kokoavasti kuvata taulukkona (taulukko 1).

TаUцUкко 1. Suomenkielisten oppijoiden vironkielisen tekstin ymmärtämisen osatekijät

\begin{tabular}{|l|l|l|}
\hline Sanasto & Rakenteet & Kielen järjestelmä \\
\hline $\begin{array}{l}\text { Substantiivit: maailm, } \\
\text { óppimine, emakeel }\end{array}$ & Päätteet ja tunnukset & Sanojen taivuttaminen \\
\hline $\begin{array}{l}\text { Pronominit: me, mida, } \\
\text { seda }\end{array}$ & $\begin{array}{l}\text { Taivutusmuodot } \\
\text { (varsinkin verbin- } \\
\text { muodot) }\end{array}$ & Sanojen yhdistäminen \\
\hline $\begin{array}{l}\text { Verbit: parandada, } \\
\text { vähendada, kohendada, } \\
\text { aitavad, on, tundub, } \\
\text { arvata, kirjutame }\end{array}$ & Yhdyssanat & Konjunktioiden käyttö \\
\hline Adverbit: tõesti & Sanajärjestys & \\
\hline Konjunktiot: et, $k u i, j a$ & & \\
\hline
\end{tabular}

Tutkimustulosten pohjalta voidaan siis todeta, että lähde- ja kohdekielen järjestelmien samanlaisuus on ymmärtämisprosessissa kaikkine osa-alueineen kokonaisvaltaisesti mukana: yhtä tärkeä kuin samanlainen sanasto on myös lähde- ja kohdekielen rakenteellinen ja funtionaalinen saman- 
kaltaisuus. Oppijoiden ymmärtämisprosessin kuvausten perusteella on syytä olettaa, että läheisen sukukielen ymmärtämisen kehityksessä kielelliset elementit ja kielen järjestelmä opitaan (lähes) samanaikaisesti. Kieltenvälinen samanlaisuus, johon ymmärtäminen perustuu, on yleensä funktionaalista ja semanttista, mutta suomenkielisten vironoppijoiden ymmärtämisprosessissa korostuu vahvasti myös rakenteellinen (formaalinen) samankaltaisuus, jonka merkityksen on väitetty olevan kielen järjestelmän oppimisessa toissijainen. Läheisen sukukielen oppija ei siis tarvitse paljon aikaa havaitakseen, miltä osin kohdekielen järjestelmä toimii samalla tavoin kuin lähdekielen järjestelmä, ja hän osaa hyödyntää sitä jo ennen varsinaisen oppimisen alkua.

Toisaalta oppijat ovat hyvinkin tietoisia siitä, ettei lähdekielen sanaa muistuttavan sanan tarvitse kohdekielessä tarkoittaa samaa kuin lähdekielessä, eli oletetun samanlaisuuden ei tarvitse välttämättä olla todellista samanlaisuutta. Tämä tieto saattaa syntyä virolais-suomalaisen "kansanlingvistiikan" pohjalta, sillä yleensä tiedetään, että toisessa kielessä on "hassuja" sanoja, mutta myös aikaisemmasta muiden kielten oppimiskokemuksesta (esimerkit 17-18):

(17) Enemmän on kuitenkin sanoja, joita en ymmärrä. Monille sanoille keksii mahdollisia merkityksiä, kun lukee niitä useampaan kertaan ja miettii rauhassa. Sanojen oikeasta merkityksestä ei voi olla aina varma.

(18) Arvelin sanoista, voi olla, että en osunut edes oikeaan.

Mahdolliset merkitykset, jotka eivät osoittaudu oikeiksi, ovat esimer-

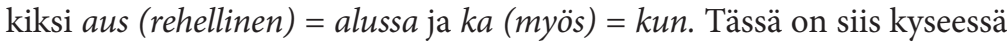
lähdekielen negatiivinen vaikutus: sanojen fonologisen ulkoasun läheisyys virossa ja suomessa johtaa oppijan harhaan sanojen merkityksen osalta.

Havaitun samanlaisuuden tärkeyttä ymmärtämisprosessissa vahvistaa myös tosiasia, että sanat ja rakenteet, jotka eivät heti aukea tai aukeavat vain kontekstissa, ovat suomessa ja virossa erilaisia. Esimerkissä (19) kommentoidaan tekstin ensimmäisen virkkeen Emakeel on inimese 
tähtsaim side maailmaga, ühiskonnaga, ligimestega. ymmärtämistä seuraavasti:

(19) Suomen illatiivia vastaava - $g a$ (on itse asiassa komitatiivi) aukeaa ennen kaikkea kontekstissa. Virkkeen viimeinen sana ligimene ei aukea.

Kukaan testiin osallistujista ei ymmärtänyt esimerkiksi sanoja mõtleme 'ajattelemme', arengus 'kehityksessä, pealiskaudselt 'pintapuolisesti', ei kõnele 'ei puhu', erandiks 'poikkeuksena', väärtuslikum 'arvokkaampi'.

Seuraavaksi pohdimme, miten ymmärtämisprosessi toimii.

\subsection{Miten ymmärretään: oppijoiden strategiat}

Oppijoiden viron kielen ymmärtämisestä kertoo se, etteivät he rajoitu pelkästään tekstin perusidean kuvaamiseen omin sanoin, vaan he myös kääntävät melko sujuvasti yksittäisiä lauseita ja lyhyempiä tai pitempiä tekstikatkelmia, kuten näkyy esimerkistä $(20)^{3}$ (ks. myös liite 1):

(20) Emakeel on inimese tähtsaim side maailmaga, ühiskonnaga, ligimestega. --- Emakeele õppimine tundub ehk mõnigi kord tüïtuna. --- Elu on väärtuslikum ja sisukam, kui suudame oma mõtteid selgelt sõnastada ning välja ütelda ja üles kirjutada nii, et ei pea kellegi ees häbenema. --- Oma väljendusvõimet parandada, vigu vähendada ja keeleasjadest arusaamist kohendada saab iga inimene kogu elu vältel.

Äidinkieli on ihmisen tärkein side maailmaan. --- Äidinkielen oppiminen tuntuu ehkä monesta turhalta. Pitäisi osata kirjoittaa niin, ettei tarvitse hävetä. Omaa kielitaitoa voi parantaa.

Yksittäiset tuntemattomat sanatkaan eivät estä tekstin osittaista kääntämistä (esimerkit 21-22):

(21) Emakeel on inimese tähtsaim side maailmaga, ühiskonnaga, ligimestega. --- Emakeele õppimine tundub ehk mõnigi kord tüütuna. --- Seda tunnet jagavad peaaegu kõik maailma õpilased.

3 Esimerkeissä (20-22) on esitetty tekstikappaleet ja niiden käännökset; lihavoituna on suomessa ja virossa samanlaiset sanat. 
Äidinkieli on yhteys maailmaan, yhteiskuntaan. --- Äidinkielen oppiminen tuntuu ehkä monista --- Sitä tunnetta jakavat ---

(22) Juba sõnugi on keeles nii palju, et neid kõiki ei tea keegi, ka keeleteadlased mitte. --- Oma väljendusvõimet parandada, vigu vähendada ja keeleasjadest arusaamist kohendada saab iga inimene kogu elu vältel. Tüdimusega on küll lugu nii, et mida rohkem miskist asjast tead, seda huvitavamaks ta muutub. Emakeelega ei ole asi teisiti.

Kielessä on niin paljon sanoja, ettei niitä kaikkia voi osata tai tietää. Omaa --- voi parantaa, virheitä vähentää, kielen lausumista (?) kohentaa koko elämän vältellä. Tutkimuksissa on todettu, että mitä enemmän jostain asiasta tietää sitä --- se tulee ja sama pätee äidinkieleen.

Oppijoiden ymmärtämisprosessissa käyttämät strategiat perustuvat kieltenväliseen havaittuun samanlaisuuteen ja lähtevät liikkeelle virossa ja suomessa samanlaisten sanojen poimimisesta tekstistä. Tunnistetut sanat auttavat ymmärtämään muitakin sanoja ja sitä kautta koko lauseen. Yhden oppijan mukaan "tutun kuuloiset sanat muodostavat yhdessä loogisen lauseen”. Tärkeä tekijä on konteksti, joka on lähdekielen pohjalta tuttujen sanojen kanssa tavallaan vuorovaikutuksessa: konteksti auttaa ymmärtämään sanoja, ja sanojen samankaltaisuus molemmissa kielissä puolestaan selventää kontekstia (esimerkit 23-25)

(23) Lauseyhteydestä pystyin päättelemään joitakin suomen sanoja muistuttavia sanoja - lauseen merkitys selkeni.

(24) Kun tunnistaa jonkun sanan, on helpompi tunnistaa muita sen ympäriltä.

(25) Kääntämisessä havaitsin siis kaksi keskeistä tekijää: suomen kielen äänteellisen vastaavuuden ja kontekstin. Konteksti vaatii avukseen yleensä joidenkin sanojen äänteellista vastaavuutta.

Mielenkiintoinen on erään oppijan toteamus siitä, että osa sanoista on helpommin tunnistettavissa ääneen luettuna, osa taas kirjoitettuna (esimerkki 26): 
(26) Koetin lukea tekstiä ääneen päässäni ja ymmärtää ja arvailla sanoja. Jos ymmärsin yhden sanan, lauseesta tai sanajärjestyksestä saattoi koettaa arvata lisää. Sanojen erilainen kirjoitusasu hämää paljon. Osa sanoista olisi helpommin ymmärrettävissä ääneen lausuttuna, osa taas paperilla näyttää tutulta.

Leksikaalista kielellisten elementtien samanlaisuutta tukee järjestelmän samanlaisuus (esimerkki 27):

(27) Vaikkei tietäisi sanojen merkityksiä, pystyy silti melko hyvin sanomaan, minkä sanaluokan sana mikäkin on. Sen voi päätellä sanajärjestyksen ja sanamuotojen (päätteet) avulla.

Oppijat osaavat hyvin havaita kahden kielen äänteellisiä vastaavuuksia ja hyödyntää vertailussa myös suomen vanhan sanaston tuntemustaan (esimerkit 28-29):

(28) Päättelin, että suomen kielen diftongit ovat virossa oienneet (kieli > keel).

(29) Tässä kohtaa myös vanhan suomen sanaston osaamisesta on hyötyä: ema-osa aukeaa suomen äitiä tarkoittavasta vanhasta vastinesta emä ja inimese vanha vastinehan on inhiminen.

Tutkimukseen osallistuneiden suomenkielisten vironoppijoiden ymmärtämisprosessissa ovat siis tärkeitä tekijöitä strateginen kompetenssi, metalingvistinen tietoisuus ja varsinkin oman äidinkielen rakenteiden, variaation ja historiallisen kehityksen perusteellinen tuntemus. Tässä yhteydessä on muistettava, että kaikki testiin osallistujat ovat kielen ammattilaisia, joille oman äidinkielen rakenne ja historia ovat tavallista tutumpia. On mahdollista, että jos tutkimus olisi tehty kokonaan toisen alan opiskelijoille tai osaajille, olisi saatu toisenlaisia tuloksia. Mielenkiintoinen kohderyhmä saattaisi olla myös suomenkieliset vieraan kielen opiskelijat. Vaikkei vieraan kielen opiskelijoilla olekaan hallussa hyvää suomen kielen historian tuntemusta, heillä on kenties joitakin kielenoppimiseen liittyviä strategioita, joista voisi olla hyötyä lähisukukielistä tekstiä tulkittaessa. 


\section{Tutkimustuloksista ja niiden didaktisesta soveltamisesta}

Miten suomenoppijaa sitten voisi auttaa ymmärtämään vironkielisiä tekstejä vähäiselläkin kielitaidolla? Edellä olevien tulosten perusteella on pääteltävissä, että kielisukulaisuus on hyödynnettävissä varsinkin sanaston tasolla. Paitsi että yksittäiset sanat muistuttavat toisiaan myös vironkielisten johdosten ja yhdyssanojen tunnistaminen on suomen puhujille yksinkertaista. Sanojen johtaminen ja yhdistäminen on suomensukuisissa kielissä loogista, minkä vuoksi näiden toimintojen oppimisen on oletettu olevan helppoa jopa indoeurooppalaista kieltä äidinkielenään puhuvalle.

Sukukielten sanat muistuttavat toisiaan eriasteisesti.Van Bezooijen ja Gooskens (2007: 256) ovat luokittaneet sanojen yhdenkaltaisuuden a) selvästi läpinäkyväksi, jolloin erilaisesta kirjoitusasusta huolimatta sanojen välillä ei ole ääntämiseroa (friisi: buro’s hollanti: bureaus), b) melko läpinäkyväksi (afrikaans: sewentig hollanti: zeventig), c) melko läpinäkymättömäksi (friisi: jierren hollanti: jaren) sekä d) täysin läpinäkymättömäksi (afrikaans: hê $\sim$ hollanti: hebben). Myös suomen ja viron sanojen samankaltaisuus on sijoitettavissa jatkumolle. Kala, lelu ja laine ovat täysin samankaltaisia, kun taas melko läpinäkyviä ovat keel, parandada ja óppida. On kuitenkin muistettava, että jokin sana saattaa olla toiselle läpinäkyvä, toiselle ei. Mahdollisten erojen - soinnillinen konsonantti vastaa soinnitonta yms. - tietoiseksi tekeminen auttaa kuitenkin sanojen vastaavuuden toteamista. Opetettaessa viroa tai suomea sanaparien käytöstä on varmasti hyötyä, erityisesti suullisessa viestinnässä. Siten harjaantuminen samaa alkuperää olevien sanojen tunnistukseen kannattaa aloittaa opintojen varhaisvaiheessa - ja näin on varmasti aina myös tehty (ks. tunnistamisesta tarkemmin Lutjeharms 2007: 279). Sanojen erilaisen kirjoitusasun ja ääntämisen huomaamiseen valmentamiseksi on laadittu tärkeimmistä muutoksista kertovia listoja (ks. esim. Kasik 1994: 10-17; Möller 2007: 288). 
Läheisten sukukielten sanastossa on aina olemassa petollisten ystävien vaara (esim. ruotsin ja englannin välisistä petollisista ystävistä ks. Ringbom 1987). Suomea ja viroa muodollisesti - luokkahuoneessa tai kursseilla - oppivat ovat niistä varmasti tietoisia, sillä viron ja suomen välisistä riskisanoista on laadittu paljon sanakirjoja (ks. esim. Alvre \& Vodja 1995). Yksittäisistä sanoista on hyödyllistä arvioida, kuinka harhaanjohtavia ne todella ovat vai voivatko ne kuitenkin ohjata ymmärtämistä oikeaan suuntaan (Möller 2007: 300). Helposti harhaanjohtavat sanaparit, kuten viro halb suomi halpa, on tietysti heti nostettava esille. Lisäksi voidaan entisestään korostaa väärinkäsityksiä ehkäisevän kontekstin tarkkailun merkitystä. Myös suurtaajuisten todellisten ystävien listaamisesta voisi olla hyötyä.

Jos ajatellaan sukulaiskieliseen tekstiin tutustumista RM-tilanteessa, olisi opittava ymmärtämis- ja tietoaukkojen sietäminen tärkeä taito. Ensilukemalla voi jäädä vielä paljon ymmärtämättä, mutta toisella lukukerralla tekstikokonaisuus antaa tukea monen tyhjän kohdan paikkaamiseen. Ymmärtämistä helpottaa lukemiseen käytettyjen strategioiden hyödyntäminen. Tieto tekstilajista ohjaa kokonaisuuden hahmottamista, ja erityisesti konteksti pohjustaa merkitysten etsimistä. Sanasta voi muistaa, missä sen on nähnyt, vaikka ei muista merkitystä, mikä auttaa eteenpäin. (Lutjeharms 2007: 271.) Lisäksi tekstin järjellisyyden oivaltamista edistävät topiikin tuntemus ja sisältöön perustuva aiempi tieto (esim. ammattialan hallinta), maailmantieto tai skeematieto. JohnsonLairdin (1983) esittämään mentaaliseen malliin (mental model; ks. myös Lutjeharms 2007: 276-277; Harley 2001: 332) sisältyy viidenlaista tietoa: spatiaalista, kausaalista, temporaalista tietoa, tietoa ihmisten päämääristä sekä ihmisten ja esineiden ominaisuuksista. Tällaisen informaation kautta voidaan päästä selville tekstin sisällöstä.

Yksittäisen sanan funktion erottamista lauseessa edistävät puolestaan morfologia ja sanajärjestys. Kun näiden kahden tason piirteet ovat varsin samanlaisia virossa ja suomessa, niiden tietoinen havainnointi on keskeistä. Tämän tutkimuksen tulosten perusteella on todettava, että läheisten sukukielten rakenteellinen samanlaisuus onkin 
tekstin ymmärtämisessä yhtä olennaista kuin sanaston samanlaisuus. Suomenkielinen oppija osaa äidinkielensä pohjalta jo valmiiksi monia asioita viron kielestä, ja äidinkielen rakenteet ovat kielten samanlaisuuden vuoksi helposti siirrettävissä. Esimerkiksi muotokategoriat ovat lähes kauttaaltaan samat, taivutusmuodot ovat samankaltaisia ja niiden muodostustapa noudattelee suunnilleen samoja sääntöjä. Suomenkielinen oppija ei tarvitse kovin paljon aikaa havaitakseen, miten viron kielen järjestelmä toimii, eli kuten edellä on todettu, kielelliset elementit ja kielen järjestelmä opitaan samanaikaisesti. Kontrastiivinen metalingvistinen tietoisuus on siis ensisijaisen tärkeä elementti; sen jatkuva kartuttaminen ja syventäminen auttavat eteenpäin hankalissa vaiheissa tuomalla korostetusti esiin lähdekielestä poikkeavia kohdekielen ilmiöitä ja kiinnittämällä niihin huomiota (Kupferberg 1999; Spada \& Lightbown 1999). Varsinkin luokkahuoneopetuksessa saattaa aiemmin omaksutun kielellisen tiedon aktivoinnista olla huomattavaa etua oppijoille (Jessner 1999). Aikaisemmat tutkimustulokset (Kaivapalu 2007, 2009) ovat osoittaneet, että vironkielisten oppijoiden suomen kielen opetuksen olisi mahdollisimman paljon pohjauduttava heidän äidinkielensä taitoihin ja tietoihin siitä; olisi tähdennettävä kieltenvälisiä samanlaisuuksia ja erilaisuuksia sekä kehitettävä tietoisuutta lähde- ja kohdekielen järjestelmistä. Tämän tutkimuksen tulosten perusteella voi todeta, että sama pätee myös suomenkielisten oppijoiden viron oppimisessa.

Sukukieliä opittaessa ja opetettaessa on mahdollista hyödyntää monenlaisia käytännön lähestymistapoja. Zeevaert ( 2007: 110) nostaa esille sukukielten (lähes) identtisten ilmausten koodaamisessa Kleinin ja Stegmannin (2000) Intercomprehension-metodin EuroComDidact-sovelluksen. Nämä ovat kehittäneet ns. seitsemän sihdin mallin (sieving in seven ways), jonka tavoitteena on oppiminen havaittujen yhtäläisyyksien perusteella. Mallissa painotetaan aiemman ja kontekstuaalisen tiedon hyödyntämistä, jotta löydettäisiin 1) kansainväliset sanat, 2) samalle kieliperheelle (tässä yhteydessä suomalaisille ja virolaisille) yhteiset sanat, 3) äänteelliset vastaavuudet (esim. suomi: $u o \sim$ viro: oo), 4) oikein- 
kirjoitussääntöjen toistuvat erot mutta myös samankaltaisuus sekä eri äänneasujen yhteinen tausta, 5) syntaktiset säännöllisyydet, 6) morfosyntaktiset säännöllisyydet ja 7) yhteiset prefiksit ja suffiksit. (Ks. myös Hufeisen \& Marx 2007: 312-319.) Samantyyppisen säännöstön suomenkielisille vironoppijoille on laatinut Kalevi Wiik (1994). Tämän tutkimuksen informanttien vastauksista on löydettävissä mainintoja juuri tällaisten menetelmien käytöstä, kuten muun muassa esimerkit (13), (16), (24) ja (26) osoittavat. Kommenteissa korostuvat sukukielten äänteellisen yhtäläisyyden, yhteisten taivutusmuotojen ja samankaltaisen sanajärjestyksen merkitys, mikä on omiaan vahvistamaan käsitystä tällaisten seikkojen esilläpidon tärkeydestä. (Äidinkielen - ja muiden osattujen kielien - pohjalta käytössä olevien lingvististen resurssien hyödyntämisestä ks. lisää Zeevaert 2007: 118-119; Lüdi 2007: 166; Dresemann 2007: 191.)

Edellä mainittujen toimintatapojen automaattistuminen (automaattistumisesta ks. Ringbom 2007: 89-94) loisi edellytykset sille, että kyettäisiin etenemään enemmän ponnistusta vaativiin prosesseihin (tuntemattomat sanat ja rakenteet). Tämän artikkelin informanttien kyky luontaisesti käyttää lingvististä päättelyään samanlaisuuden oivaltamiseksi johtuu osittain heidän koulutuksestaan, mutta kyseisten strategioiden tietoinen opettaminen olisi taloudellinen, nopeasti tulosta tuottava ratkaisu kaikille oppijoille tai muuten vain virosta kiinnostuneille.

\section{Lopuksi}

Vaikka reseptiivistä monikielisyyttä on jo kauan hyödynnetty viron ja suomen omaksumisessa ja opettamisessa, siihen on avattavissa uusiakin näkökulmia. Yhtenä tavoitteena voisi olla esimerkiksi sellaisen ohjeiston kehittäminen, joka helpottaisi kenen tahansa sukukielestä kiinnostuneen perehtymistä kohdekieliseen tekstiin tai tukisi mahdollisia opintoja jo varhaisessa vaiheessa. Tällöin saataisiin mahdollisuus lisäsyötöksen hankkimiseen ja sitä kautta avattaisiin ikkunoita niin kohdekieleen kuin -kulttuuriinkin. 
Vaikka reseptiivinen monikielisyys tuntuukin tarjoavan monia etuja, herättää se myös monia kysymyksiä. Voi olla, että RM on liian vastaanottajakeskeinen näkökulma. Reseptiivinen kompetenssi mahdollistaa helpohkon tekstin, jopa toisen puheen ymmärtämisen, mutta se ei vielä tietenkään riitä takaamaan onnistunutta interaktiota, jossa osallistujat yhdessä rakentavat mielekästä ja vastavuoroista keskustelua ja jossa nimenomaan kommunikatiivisella kompetenssilla on keskeinen merkitys. Tässä artikkelissa on keskitytty luetun ymmärtämisen edellytysten tarkasteluun, mutta missä määrin RM on realistinen ja toteutettavissa oleva suullisenkin viestinnän malli suomi-viro-kontakteissa Skandinavian tapaan? Milloin RM on mahdollista? Vilkastunut matkailu, maahanmuutto - ennen kaikkea Suomen suuntaan - sekä liike-elämän ulottuvuudet luovat jatkuvasti tilanteita, joissa niin puhutun kuin kirjoitetunkin tekstin ymmärtämisestä on hyötyä. Käytännössä RM-vuorovaikutusta toki on ja on ollut, mutta tutkimusta tarvitaan. Tutkimustulosten soveltamisen kautta on kehitettävissä ymmärtämistä ja oppimista entistä tehokkaammin edistäviä menetelmiä.

Kiinnostava peruskysymys on, täyttyvätkö monikielisen kommunikaation edellytykset: onko virolaisten ja suomalaisten ylipäänsä ilman jonkintasoista opiskelua mahdollista ymmärtää toisiaan ja kuinka hyvin? Esimerkiksi norjalaiset ymmärtävät kahta muuta skandinaavista kieltä paremmin kuin muut. Syynä on muun muassa norjalaisten kiinnostus naapurimaistaan; lisäksi he ovat tottuneet kielelliseen variaatioon (maassa kaksi kirjakieltä ja lukuisia kaikissa tilanteissa hyväksyttyjä murteita), ja pienessä kieliyhteisössä monikielisyys on yleensä suositumpaa kuin suurissa (Delsing 2007: 234-244; Doetjes 2007: 220). Siten motivaatio RM-kommunikaatioon voi vaihdella. Olisikin selvitettävä, millainen tilanne vallitsee tällä hetkellä Virossa ja Suomessa. Suomen kielen taito on ratkaisevasti kadottanut viehätysvoimaansa Viron itsenäistyttyä 1990-luvulla, mutta vähitellen halukkaita oppijoita on taas ilmaantunut. Tosin toisin kuin on väitetty, postitiivisten asenteiden ja ymmärtämisen välillä ei välttämättä ole positiivista korrelaatiota, toteavat hollantia ja sen suhdetta friisiin tai afrikaansiin 
tutkineet van Bezooijen ja Gooskens (2007: 254). Jos sekä virolaiset että suomalaiset käyttäisivät vuorovaikutuksessa äidinkieltään, kohtaamisen lähtökohdat olisivat kuitenkin tasa-arvoiset, mikä on aina eduksi. Haastava käytännön kysymys on se, kuka, miten ja missä saisi tietää RM-mahdollisuudesta ja monikielistä viestintää helpottavista seikoista.

Jos RM-tutkimustuloksilla on tarkoitus hyödyttää viron ja suomen opettamista, on tietysti perusteellisesti harkittava, ovatko edellisessä luvussa esitellyt didaktiset pohdinnat relevantteja. Useat teoreettiset oivallukset ja didaktiset sovellukset ovat voittopuolisesti syntyneet olosuhteissa, joissa monikieliseen tilanteeseen osallistuvat ovat indoeurooppalaisten kielten puhujia. Kun viron ja suomen opiskelu viime vuosituhannen viimeisinä vuosikymmeninä lisääntyi, törmättiin jatkuvasti siihen, että toisen kielen omaksumista ja opettamista koskeva tutkimus sovelluksineen perustui indoeurooppalaisiin kieliin eikä siten aina ollut hyödynnettävissä suomalais-ugrilaisten kielten tutkimuksessa tai niiden opettamisessa. Sama "vääristymä" voi olla mahdollinen myös RM-tutkimuksesta puhuttaessa. Viron ja suomen erityispiirteiden huomioonotto on tietysti ensiarvoisen tärkeää, sillä muuten annettavat ohjeet osoittautuvat liian yleisinä käyttökelvottomiksi.

Joka tapauksessa tutkimusta tarvitaan lisää. Olisi ratkaistava esimerkiksi se, miten voisi tutkia ja testata suullisten RM-tilanteiden todellista ymmärtämistä. Yksi pulma on hankitussa aineistossa todennäköisesti esiintyvän mukautetun viron ja oppijansuomen erottaminen toisistaan; rajan vetäminen on erittäin hankalaa. Pohjoisvirolaisen passiivinenkin suomenomaksunta voi tuottaa kielivarieteetin, joka on nimitettävissä oppijansuomeksi. Silloin ei enää toteudu RM:n peruslähtökohta, jossa molemmat osapuolet puhuisivat äidinkieltään vain lievästi mukauttaen. Olisi kaiken kaikkiaan kyettävä hankkimaan aineistoa, jossa molemmilla osallistujilla on suurin piirtein samanlaiset edellytykset ymmärtää toistensa kieltä. Täten virolaisiksi informanteiksi soveltuisivat parhaiten etelävirolaiset, joilla on vähemmän kontakteja suomalaisten kanssa kuin pohjoisvirolaisilla. Testattavaksi on saatava myös muita kuin kieli- 
ammattilaisia, jotta saataisiin kuva myös ei-lingvistin kielellisestä päättelystä ja strategioinnista.

Kirjallisten tekstien ymmärtämisen tutkimus on ulotettavissa paitsi viron myös suomen kieleen. Itä-Suomen, Jyväskylän ja Tallinnan yliopistojen yhteishankkeena on viritetty REMU-tutkimus (Receptive Multilingualism), jonka tavoitteena on jatkaa Kaivapalun aloittamaa sukukielisen tekstin ymmärtämisen tutkimusta. Kun saadaan lisätietoa siitä, millä tavoin sukukieltä osaamaton tekstin saloja selvittelee, on mahdollista miettiä, miten käytetyt strategiat ovat sovellettavissa viron ja suomen opetukseen tai miten niitä voidaan hyödyntää neuvottaessa matkailijoita tai monikulttuurisia työntekijöitä arjen tekstien kohtaamiseen.

\section{Lähteet}

Alvre, Paul, Raul Vodja 1995. Pulma poikineen. Virolais-suomalainen vertailusanakirja. Porvoo, Helsinki, Juva: WSOY.

Braunmüller, Kurt 2007. Receptive multilingualism in Northern Europe in the Middle Ages. A description of a scenario. - Jan D. ten Thije, Ludger Zeevaert (Eds.). Receptive Multilingualism. Linguistic Analyses, Language Policies and Dialectic Concepts. Hamburg Studies on Multilingualism 6. Amsterdam: John Benjamins, 25-47.

Dechert, Hans W., Manfred Raupach 1989. Introduction. - Hans W. Dechert, Manfred Raupach (Eds.). Transfer in Language Production. Norwood, New Jersey: Ablex Publishing Corporation, ix-xvii.

Delsing, Lars-Olof 2007. Scandinavian intercomprehension today. - Jan D. ten Thije, Ludger Zeevaert (Eds.). Receptive Multilingualism. Linguistic Analyses, Language Policies and Dialectic Concepts. Amsterdam: John Benjamins, 231-246.

Doetjes, Gerard 2007. Understanding differences in inter-Scandinavian language understanding. - Jan D. ten Thije, Ludger Zeevaert (Eds.). Receptive Multilingualism. Linguistic Analyses, Language Policies and Dialectic Concepts. Amsterdam: John Benjamins, 217-230.

Dresemann, Bettina 2007. Receptive multilingualisn in business discourses. - Jan D. ten Thije, Ludger Zeevaert (Eds.). Receptive Multilingualism. Linguistic Analyses, Language Policies and Dialectic Concepts. Amsterdam: John Benjamins, 179-193. 
Harley, Trevor 2001. The Psychology of Language. Hove: Psychology Press. doi:10.4324/9780203345979

Haugen, Einar 1966. Language Conflict and Language Planning: the Case of Modern Norwegian. Cambridge, Mass.: Harvard University Press.

Hint, Mati 1983. Eesti keele õpik IX klassile. Tallinn: Valgus.

Eckman, Fred 2004. From phonemic differences to contrast ranking: Research on second language phonology. - Studies in Second Language Acquisition 26, 514-539. doi:10.1017/S027226310404001X

Hufeisen, Britta, Nicole Marx 2007. How can DaFnE and EuroComGerm contribute to the concept of receptive multilingualism. - Jan D. ten Thije, Ludger Zeevaert (Eds.). Receptive Multilingualism. Linguistic Analyses, Language Policies and Dialectic Concepts. Amsterdam: John Benjamins, 307-321.

Jarvis, Scott 2000. Methodological rigor in the study of transfer: Identifying L1 influence in the interlanguage lexicon. - Language Learning 50 (2), 245-309. doi:10.1111/0023-8333.00118

Jessner, Ulrike 1999. Metalinguistic awareness in multilinguals: Cognitive aspects of third language learning. - Language Awareness 8, 201-209. doi:10.1080/09658419908667129

Johnson-Laird, Philip N. 1983. Mental Models: Towards a Cognitive Science of Language, Inference and Consciousness. Cambridge: Cambridge University Press.

Kaivapalu, Annekatrin 2004. Kui sarnane on sarnane? Eesti ja soome mitmusevormide psühholingvistilisest reaalsusest. - Helena Sulkala, Heli Laanekask (Toim.). VIRSU II. Suomi ja viro kohdekielinä. Oulun yliopiston suomen ja saamen kielen ja logopedian laitoksen julkaisuja 24. Oulu, 62-71.

Kaivapalu, Annekatrin 2006. Reeglid ja analoogia võõrkeeleõppes soome mitmusevormide käänamise näitel. - Eesti Rakenduslingvistika Ühingu aastaraamat 2, 71-92.

Kaivapalu, Annekatrin 2007. Äidinkieli vieraiden kielten opiskelussa - etu vai haitta? - Olli-Pekka Salo, Tarja Nikula, Paula Kalaja (Toim.). Kieli oppimisessa - Language in Learning. AFinLA:n vuosikirja 65. Jyväskylä: AfinLA, 289-309.

Kaivapalu, Annekatrin 2009. Vironkielisen suomenoppijan äidinkieli - ongelma, haaste vai voimavara? - Virittäjä 3, 382-402.

Kasik, Reet 1994. Hakkame rääkima! Viron kielen peruskurssi. Turun yliopiston suomalaisen ja yleisen kielitieteen laitoksen julkaisuja 37. Turku: Turun yliopisto. 
Klein, Horst G., Tilbert D. Stegmann 2000. EuroComRom - Die sieben Siebe: Romanische Sprachen sofort lesen können. Aachen: Shaker Verlag.

Kupferberg, Irit 1999. The cognitive turn of contrastive analysis: Empirical evidence. - Language Awareness 8, 210-222. doi:10.1080/09658419908667130

Laakso, Johanna 2007. Suomi ja viro rinnakkain ulkomaanfennougristiikassa. Pirkko Muikku-Werner, Ossi Kokko, Hannu Remes (Toim.). Virsu III: Suomalais-ugrilaisia kohdekieliä ja kontakteja. Studies in Languages 42. Joensuu: Joensuun yliopisto, 9-18.

Laanekask, Heli 2003. Kommunikatsioonistrateegiatest Lydia Koidula eesti-soome vahekeeles. - Pirkko Muikku-Werner, Hannu Remes (Toim.). Viro ja suomi: kohdekielet kontrastissa. Lähivertailuja 13. Joensuu: Joensuun yliopisto, 265-275.

Lutjeharms, Madeline 2007. Processing levels in foreign-language reading. - Jan D. ten Thije, Ludger Zeevaert (Eds.). Receptive Multilingualism. Linguistic Analyses, Language Policies and Dialectic Concepts. Pragmatics \& Beyond New Series 144. Amsterdam: John Benjamins, 267-284.

Lüdi, Georges 2006. Multilingual repertoires and the consequences for linguistic theory. - Kristin Bührig, Jan D. ten Thije (Eds.). Beyond Misunderstanding. Linguistic Analyses of Intercultural Communication. Amsterdam: John Benjamins, 11-42.

Lüdi, Georges 2007. The Swiss model of plurilingual communication. - Jan D. ten Thije, Ludger Zeevaert (Eds.). Receptive Multilingualism. Linguistic Analyses, Language Policies and Dialectic Concepts. Amsterdam: John Benjamins, 159-178.

Malt, Barbara C., Steven A. Sloman, Silvia P. Gennari 2003. Universality and language specificity in object naming. - Journal of Memory and Language 49, 20-42. doi:10.1016/S0749-596X(03)00021-4

Meißner, Franz-Joseph, Ulrike Senger 2001. Vom induktiven zum konstruktiven Lehr- und Lernparadigma. Methodische Folgerungen aus der mehrsprachigkeitsdidaktischen Forschung. - Franz-Joseph Meißner, Marcus Reinfried (Hrsg.). Bausteine für einen neukommunikativen Französischunterricht. Tübingen: Narr, 21-50.

Meißner, Franz-Joseph 2002. EuroComDidact. - Dorothea Rutke (Hrsg.). Europäische Mehrsprachigkeit. Analysen - Konzepte - Dokumente. Aachen: Shaker Verlag, 45-64.

Möhle, Dorothea, Manfred Raupach 1989. Language transfer of procedural knowledge. - Hans W. Dechert, Manfred Raupach (Eds.). Transfer in 
Language Production. Norwood, New Jersey: Ablex Publishing Corporation, 195-216.

Möller, Robert 2007. A computer-based exploration of the lexical possibilities of intercomprehension. Finding German cognates of Dutch words. - Jan D. ten Thije, Ludger Zeevaert (Eds.). Receptive Multilingualism. Linguistic Analyses, Language Policies and Dialectic Concepts. Amsterdam: John Benjamins, 283-305.

Neuner-Anfindsen, Stefanie 2005. Fremdsprachenlernen und Lernerautonomie. Spraclernbewusstsein, Lernprozessorganisation und Lernstrategien zum Wortschatzlernen in Deutsch als Fremdsprache. Baltmannsweiler: Schneider Hohengehren.

Nikko, Tuija 2009. Dialogic Construction of Understanding in Cross-border Corporate Meetings. Helsinki: Helsinki School of Economics.

Odlin, Terrence 1989. Language Transfer. Cross-linguistic Influence in Language Learning. Cambridge: Cambridge University Press.

Remes, Hannu 2009. Muodot kontrastissa: suomen ja viron vertailevaa taivutusmorfologiaa. Acta Universitatis Ouluensis. Serie B, Humaniora. Oulu: Oulun yliopisto.

Ribbert, Anne, Jan D. ten Thije 2007. Receptive multilingualism in Dutch-German intercultural team cooperation. - Jan D. ten Thije, Ludger Zeevaert (Eds.). Receptive Multilingualism. Linguistic Analyses, Language Policies and Dialectic Concepts. Amsterdam: John Benjamins, 72-101.

Ringbom, Håkan 1987. The Role of the First Language in Foreign Language Learning. Clevedon: Multilingual Matters.

Ringbom, Håkan 2007. Cross-linguistic Similarity in Foreign Language Learning. Clevedon: Multilingual Matters LTD.

Sajavaara, Kari 1999. Kontrastiivinen kielentutkimus ja virheanalyysi. - Kari Sajavaara, Aira Piirainen-Marsh (Toim.). Kielenoppimisen kysymyksiä. Jyväskylä: Jyväskylän yliopisto, 103-128.

Sajavaara, Kari 2006. Kontrastiivinen analyysi, transfer ja toisen kielen oppiminen. - Annekatrin Kaivapalu, Külvi Pruuli (Toim.). Lähivertailuja 17. Jyväskylä Studies in Humanities 53. Jyväskylä: Jyväskylän yliopisto, 9-26.

Spada, Nina, Patsy M. Lightbown 1999. Instruction, first language influence, and developmental readiness in second language acquisition. - Modern Language Journal 82 (1), 1-22. doi:10.1111/0026-7902.00002

Van Bezooijen, Renée, Charlotte Gooskens 2007. Interlingual text comprehension. Linguistic and extralinguistic determinants. - Jan D. ten Thije, Ludger 
Zeevaert (Eds.). Receptive Multilingualism. Linguistic Analyses, Language

Policies and Dialectic Concepts. Amsterdam: John Benjamins, 249-263.

Wiik, Kalevi 1994. Suomalaisten yksisivuinen viron kielioppi. - Helena Sulkala,

Heli Laanekask (Toim.). Lähivertailuja 8. Suomalais-virolainen kontrastiivinen seminaari Hailuodossa 7.-9.5.1994. Oulu: Oulun yliopisto, 124-128.

Zeevaert, Ludger 2007. Receptive multilingualism and inter-Scandinavian semicommunication. - Jan D. ten Thije, Ludger Zeevaert (Eds.). Receptive Multilingualism. Linguistic Analyses, Language Policies and Dialectic Concepts. Amsterdam: John Benjamins, 103-135.

Zeevaert, Ludger, Jan D. ten Thije 2007. Introduction. - Jan D. ten Thije, Ludger Zeevaert (Eds.). Receptive Multilingualism. Linguistic Analyses, Language Policies and Dialectic Concepts. Amsterdam: John Benjamins, 1-21.

\section{Liite 1. Mati Hint "Eesti keele õpik IX klassile" (1983: 3-4)}

Emakeel on inimese tähtsaim side maailmaga, ühiskonnaga, ligimestega. Emakeeles me mõtleme ning enamasti ka ütleme ja kirjutame kõik selle, mis meie elus on tõesti tähtsat. Emakeeleoskuse tasemest sõltub inimese arengus palju rohkem kui pealiskaudselt võib arvata.

Emakeele õppimine tundub ehk mõnigi kord tüütuna. Seda tunnet jagavad peaaegu kõik maailma õpilased. Vahel võib koguni paista, et milleks ikka õppida seda, mida nagunii oskad. Päris kirjaniku moodi just ei kirjuta ega kõnele, aga kuidagi saab läbi. Ent igasugune keeleoskus (ja emakeel ei ole siin erandiks) on niisugune asi, mis päris valmis ei saa kunagi. Keele võimalused on piiritud. Juba sõnugi on keeles nii palju, et neid kõiki ei tea keegi, ka keeleteadlased mitte. Oma väljendusvõimet parandada, vigu vähendada ja keeleasjadest arusaamist kohendada saab iga inimene kogu elu vältel. Kohaseim iga selleks on kooliaeg.

Aus sõnaosavus ja selge mõtlemine aitavad meid ka eluvõitluses. Elu on väärtuslikum ja sisukam, kui suudame oma mõtteid selgelt sõnastada ning välja ütelda ja üles kirjutada nii, et ei pea kellegi eest häbenema. Sellepärast tuleb emakeelega pidevalt tegelda ning mõnikord ka ületada tüdimustunne selle juures. Tüdimusega on küll lugu nii, et mida rohkem miskist asjast tead, seda huvitavamaks ta muutub. Emakeelega ei ole asi teisiti. 


\title{
Receptive multilingualism: How Finnish as a first language helps learners to understand Estonian?
}

\author{
ANNEKATRIN KAIVAPALU \\ Tallinn University \\ PIRKKO MUIKKU-WERNER \\ University of Eastern Finland
}

The Council of Europe language policy recommends that all European citizens learn at least two foreign languages. If this is put to practice, the methods of endorsing learning and the required proficiency need to be discussed. Would it suffice for most people just to understand the foreign language? A potentially useful construct is receptive multilingualism: the participants of a conversation each use their native language which the other person understands. Such an approach is not a novelty; it has been favoured in Scandinavian collaboration for a long time. If comprehension were the principle goal of language learning, a language closely related to one's first language or other languages already known would be an economical choice for study. Thus for Finns to learn Estonian, and vice versa, is both useful, due to many contacts, and feasible, due to linguistic proximity. This would provide a practical alternative for both parties using a foreign language, usually English.

The idea of receptive multilingualism in communication between Estonians and Finns is an attractive idea. Since receptive multilingualism is first and foremost about second language comprehension, a test was designed for assessing that. Finnish students with no prior knowledge of Estonian were given a text in Estonian and then asked to describe its contents in writing. Translating was also encouraged. In addition, the students were asked to reflect on the experience: to describe what was easy, what was difficult, and what strategies were used in retrieving the meaning. As expected, the results showed that particularly similarities in the vocabulary facilitated understanding. The learners were also aware of the existence of false friends: the similarity of form was not blindly trusted to provide a shared meaning. The structural proximity of the languages was 
equally essential in understanding the text: the similarity of inflection, derivation, compounding, and sentence structure aided in deciphering the contents of the text. Unlike production, the comprehension of closely related languages proceeds with simultaneous item learning and system learning. It is also possible to deduct from the answers that strategic competence, metalinguistic awareness and profound knowledge of one's first language all support comprehension.

Keywords: acquisition of related language; receptive multilingualism; text comprehension; crosslinguistic influence; learner strategies; Estonian; Finnish

\section{Annekatrin Kaivapalu}

Tallinna Ülikool, eesti keele ja kultuuri instituut

Narva mnt 29

10120 Tallinn, Estonia

kaivapa@tlu.ee

\section{Pirkko Muikku-Werner}

Itä-Suomen yliopisto

Humanistinen osasto, suomen kieli ja kulttuuritieteet

PL 111

FI-80101 Joensuu, Finland

pirkko.muikku-werner@uef.fi 